\title{
THE GEOGRAPHY OF REBELLION: STRATEGY AND SUPPLY IN THE TWO 'SICILIAN SLAVE WARS'*
}

\section{PETER MORTON}

In Book 36 of his Bibliotheke, Diodorus Siculus tells us that following three years of war between the rebel slaves of Sicily and the forces of Rome, starting in $104,{ }^{1}$ M'. Aquilius fought and killed the rebel leader Athenion in single-combat, and in the process broke the back of the resistance (Diod. Sic. 36.10.1). ${ }^{2}$ Within the next year, the remaining rebel forces were sought out, defeated, and punished. This conflict signalled the end of Rome's military involvement in Sicily, and in particular a 40 year period made exceptional by the eruption of two significant, and apparently unexpected, wars: already in 135, Rome found itself engaged with rebel forces in a conflict that required three years of Rome's attention to be settled in Rome's favour.

We owe much of our knowledge of these two wars to Diodorus Siculus who has enshrined the events in later memory as the First and Second Sicilian Slave Wars. This conceptualisation of the two conflicts as 'First' and 'Second' has remained to this day. A consequence of this approach is that the two wars are typically studied in tandem, and that essential elements of these conflicts are a priori understood to be the same or similar. This

\footnotetext{
* I would like to thank Ulrike Roth and Keith Rutter, as well as the editor of BICS, John North, and Michael Crawford for their help and insight in improving this article. I am also very grateful to the editors of Diodorus Siculus: shared myths, world community, and universal history, Lisa Hau, Alexander Meeus, and Brian Sheridan, for allowing me to see an advance version of Wozniczka's article. The mistakes throughout remain my own. The text of Diodorus is that of the Loeb Classical Library: F. R. Walton, ed. and trans., Diodorus of Sicily, 12 vols (Cambridge 1933-67) XII (1967); all translations are mine. The definitive version is available at http://www3.interscience.wiley.com/.

DOI: http://onlinelibrary.wiley.com/doi/10.1111/j.2041-5370.2014.00063.x/pdf

${ }^{1}$ All dates are $\mathrm{BC}$ unless specified otherwise.

2 This duel does not, however, appear to have been one started by a formal challenge, for which see S. P. Oakley, 'Single combat in the Roman Republic', CQ 35.2 (1985) 392-410.
} 
applies for instance to the question of the rebels' strategies and supply mechanisms. In his detailed study of the strategy of the two wars, Strauss consistently assumed that the two conflicts were of a similar nature, and, consequently, he conceptualised specific elements as well as the wars on the whole as alike: ${ }^{3}$

From a military point of view, [the slave revolts] demonstrate the unlikelihood of insurrections defeating regular armies...They could march their men in mock legions and defeat frightened local militia... Once the state bore down on them with all its might, however, they faced ruin. (my emphasis)

On the other hand owing to the typical interest among scholars in the slave element of the wars, the two conflicts have been placed in a separate category of analysis from other wars, even so far as their martial aspects are concerned. ${ }^{4}$ As a result, scholars have typically denied the rebel forces the skill, knowledge, experience and resources required for any serious or sustained military strategies. Thus, as early as 1965, Vogt dismissed the idea of a rebel strategy beyond a disorganised guerrilla campaign: ${ }^{5}$

So ist denn auch in Sizilien von einer Strategie der Sklavenführer kaum zu sprechen. Wenn Salvius die Städte vermied und seinen Haufen in drei Abteilungen das Land durchziehen ließ (Diod. 36, 6, 4), so machte er aus der Not eine Tugend, denn die Städte schlossen ihre Tore. Man kann seine Kriegführung, wohl auch die des Eunus, als einen das offene Land terrorisierenden Partisanenkampf bezeichnen.

\footnotetext{
${ }^{3}$ B. Strauss, 'Slave wars of Greece and Rome', in Makers of ancient strategy, ed. V. D. Hanson (Oxford 2010) 185-205 (201).

${ }^{4}$ For example, Strauss, 'Slave wars' (n. 3, above) 201 called the wars 'insurrections', and compared them to modern 'insurgencies', rather than 'wars'.

${ }^{5}$ J. Vogt, Sklaverei und Humanität: Studien zur antiken Sklaverei und ihrer Erforschung, (Wiesbaden 1965) 47.
} 
In the same regard, Bradley, drew on comparisons with modern slavery, and in particular the phenomenon of marronage, to explain the rebel actions. ${ }^{6}$ And just as the two rebel forces and their actions have in essence been understood as alike, so have the Roman responses to the conflict: Shaw, for example, described Rome's approach as 'lethargic' on the one hand, and as 'inadequate' on the other. ${ }^{7}$

The 'harmonising' approach of modern scholarship to the two wars that Diodorus calls the First and Second Sicilian Slave Wars has led to a near complete neglect of the strategic complexities of the two conflicts. In this article, I aim to demonstrate that we must, in contrast, consider the two conflicts as separate entities, and that we must approach the study of these wars as we would any other wars - that is, without any assumptions about the strategies employed or the supply mechanisms put in place. The role of logistics and supply in the two Sicilian 'Slave Wars' is an understudied aspect of the two conflicts. When studied from the perspective of maintenance the typical focus has been on the monarchical structures used, or on the maintenance of slave numbers. ${ }^{8}$ Thus, I will argue that the role played by the island of Sicily itself, as well as the logistics of warfare, is far more integral to comprehending the rebel strategies than has been allowed in the past. By doing this, we will see that the rebels in the first war prosecuted the conflict in a highly strategic manner, which presents a stark contrast with the confused and ineffectual efforts of the rebels in the second

${ }^{6}$ K. R. Bradley, Slavery and rebellion in the Roman World, 140 B.C. - 70 B.C., (Bloomington 1989) xiv-xv and 123-26.

${ }^{7}$ B.D. Shaw, Spartacus and the Slave Wars: a brief history with documents, (Boston 2001) 12. Similarly, R. Martínez-Lacy, 'Fear as a factor in slave revolts', in Fear of slaves - fear of enslavement in the Ancient Mediterranean, ed. A. Serghidou (Franche-Comte 2007) 35-38 suggested that the Roman response was not sufficiently shaped by the fear they should have felt regarding the revolts, and this allowed them to escalate further than they should have.

${ }^{8}$ For discussions of the monarchical structure, see e.g. J. C. Dumont, Servus. Rome et l'esclavage sous la République, (Rome 1987) 213-71; G. Wirth, Katastrophe und Zukunftshoffnung, (Wien 2006) 124-29; T. Urbainczyk, Slave revolts in antiquity, (Stocksfield 2008) 29-50. G. Manganaro, 'La provincia romana', in La Sicilia antica, ed. E. Gabba and G. Vallet (Naples 1980) 411-61 (441) briefly considered the maintenance of the rebellions, although not in the context of supply and strategy, noting of the so-called Second Sicilian Slave War that '(1)a participazione anche in questa rivolta di nullatenenti liberi, gli 'aporoi', contribuì a prolungare lo stato di guerra, accrescendo le perdite di vite umane e di beni.' Bradley, Slavery and rebellion (n. 6, above) 102-26 focused on four areas of maintenance: acquisition of weapons (104-09); procurement of food (109-11); maintenance of 'slave' leadership (111-23); and the growth of rebel numbers (123-26). His greatest focus was on the leadership of the revolts as a matter of maintenance, with only a very brief discussion of food supply. 
war. Understanding this contrast, we will see that the two wars cannot be regarded as iterations of the same basic phenomenon: they were at the very least strategically distinct events, suggesting in turn deeper differences between the two.

\section{The Rebel Strategies}

In this section, an attempt will be made to sketch out the potential strategies employed by the rebels. Of necessity, the outlines proposed will be tentative, intended more as suggestions than definite proofs. This will be especially the case given the paucity of our source material, the bias of ancient literary evidence towards a Romano-centric point of view of the conflicts, and, not least, the fact that the rebels lost. It is important to remember that the eventual (and, perhaps, inevitable) defeat suffered by the rebels does not negate the importance of how they fought, and the potential problems this caused for Rome. Nor should their defeat suggest, automatically, that the rebels fought without strategy or skill. Even more so than this, we must not assume that in both conflicts the same essential strategic features were present.

\section{I.i. The Geographical Context}

An important aspect of this new approach is the close analysis of the relationship between Sicily's difficult, mountainous terrain and its network of roads. The location of roads in Sicily in antiquity is of central importance to understanding major events such as the two under discussion here and the problems that the armies on both sides faced. We should start with a peculiarity of the island: quite unlike on mainland Italy, Roman input into the roads of Sicily is very limited. Despite their repeated military activity on the island throughout the third century BC, there is evidence for only two stretches of road built by the Romans before the second century BC, and this evidence is limited. First, there is a road from Agrigentum to Himera, built by Aurelius Cotta in 252, evidenced by a single miliarium bearing the consul's name; ${ }^{9}$ second, there is a road from Messana to Lilybaeum, most likely built by Valerius

\footnotetext{
${ }^{9}$ G. P. Verbrugghe, Itinera romana: Sicilia, (Bern 1976) 19-22; G. Uggeri, La viabilità della Sicilia in età romana, (Galatina 2004) 70-71. See also J. R. W.Prag, 'Il miliario di Aurelius Cotta (ILLRP 1277): una lapide in contesto', in Guerra e pace in Sicilia nel Mediterraneo antico (VIII-III sec. a.C.). Arte, prassi e teoria della pace e della guerra, ed. M. A. Vaggioli (Pisa 2006) 733-44 for further consideration of the meaning of this miliarium.
} 
Laevinus in 214, for which there is no explicit evidence beyond Strabo's mention (6.2.1) of the via Valeria between Drepanum and Messana. ${ }^{10}$ Otherwise it does not appear that Rome engaged in any other significant construction or even upkeep of Sicilian roads. ${ }^{11}$

All the other roads in Sicily were Greek and Carthaginian routes that traversed between the major towns of the island. The Romans left them unchanged and unimproved (Map 1). ${ }^{12}$ There are significant limitations in this road system. Apart from long coastal routes, ${ }^{13}$ there were only two roads from the south-east of the island to the north: one of them ran through Enna; the other allededly ran from Agyrium to Halaesa, branching away from the route from Catana to Enna, some 15 miles east of Enna. ${ }^{14}$ While the plains of Leontini and

${ }^{10}$ See Verbrugghe, Itinera (n. 9, above) 50-52; Uggeri, La viabilità (n. 9, above) 117-18.

${ }^{11}$ For the east in particular, G. Salmeri, Sicilia romana: storia e storiografia, (Catania 1992) 17 noted that

'...l'arrivo dei Romani non sembra aver portato alla creazione di nuove strade'. Uggeri, La viabilità (n. 9, above) 24 commented that after, at the latest, the work of C. Norbanus (82-80) in improving the via Pompeia (possibly the via Valeria; see Verbrugghe, Itinera (n. 9, above) 52-54), there was no further Roman input into the roads.

${ }^{12}$ In the two major discussions of the roads of Sicily, Verbrugghe, Itinera (n. 9, above) and Uggeri, La viabilità (n. 9, above), there is no distinction made between 'roads' and 'routes'. However, the major roads discussed in this article are largely attested through a combination of: a) archaeological evidence or aerial photography, which includes the remaining bridges as well as the trazzere, or sheep trails of Sicily, b) literary evidence such as Strabo, Diodorus or Cicero for the movements of armies through Sicily, c) cartographical evidence, including the tabula Peutingeriana, d) epigraphic evidence, and finally e) the study of toponyms - for all these see Verbrugghe, Itinera (n. 9, above) 18-27 and 45-52, and Uggeri, La viabilità (n. 9, above) 29-94. The exact construction of these roads is unclear, although Uggeri, La viabilità (n. 9, above) 19 did suggest that the roads of the Greek and Carthaginian period were good enough to allow fast movement of cavalry. In this article, therefore, the term 'roads' is used to mean a route of access in some way improved enough to allow the fast passage of armies and their attendant baggage trains.

${ }^{13}$ Uggeri, La viabilità (n. 9, above) 297 noted that the roads of Sicily favoured the coast, and not the interior.

${ }^{14}$ Uggeri, La viabilità (n. 9, above) 58 and 279-80 argued that the Ravenna itinerary records a route from Herbita - the exact location of which is uncertain, although it is probably not far off the north-east coast of Sicily - and down through Agyrium to Enna. He also cited the passage of Cicero in which Cicero commented that the citizens of Enna could get their grain to any of Halaesa, Phintias or Catana in a day (2.3.192). This statement Uggeri took to mean that there was a route between Halaesa and Enna used for the transport of wheat, and that this later became the route in the Ravenna itinerary. The only evidence for ancient routes in this area are mule tracks (Uggeri, La viabilità (n. 9, above) 279), which makes it hard to gauge the quality of the road. Moreover, Cicero's claim that the route was traversable in a day is problematic: a donkey walks, when laden with $80 \mathrm{~kg}$, at 2.5 miles per hour, giving a donkey a range of 60 miles in 24 hours of non-stop walking. The 
the fertile fields of the south-east are criss-crossed with various different short roads, ${ }^{15}$ the only roads that run right across the area are either from Agrigentum to Syracuse, or Agrigentum to Catana. ${ }^{16}$ Furthermore, the west of the island is connected to the east only through three routes: the two southern routes to Syracuse and Catana; the route from Himera down through Enna and on to Catana; and finally the northern route from Himera to Messana, which then goes down the east coast through Tauromenium to Catana. ${ }^{17}$ All the routes could be controlled through a combination of Agrigentum in the south, Himera in the north, Enna in the middle of the island, and either Messana or Tauromenium in the north-east.

These realities of traversing Sicily are evident throughout the history of the island. In the First Punic War, during the siege of Agrigentum in 262, the Romans had set up a magazine of supplies at Herbessus (Polyb. 1.18.5), which the Carthaginian army under Hanno then captured (1.18.9). This encirclement could only be intermittently broken by Hiero's efforts at supplying the Roman forces, leading to the Romans facing extreme duress in their siege (1.18.10-11). In the event, the Roman forces only relieved the pressure by defeating the Carthaginian force under Hanno in open battle, thereby opening up again their lines of communication. It is clear, even from the limited narrative preserved by Polybius, that with the capture of Herbessus by the Carthaginians, Rome lost control of easy access to the east.

distance (by modern roads) from Enna to Halaesa is 58.5 miles, or 23.4 hours by donkey, but this is over a mountain range (see Uggeri, La viabilità (n. 9, above) 58 and 279-80, for details of the route and J. M. King, 'Livestock and water needs in pastoral Africa in relation to climate and forage', ICLA Report No. 7 (International Livestock Centre for Africa 1983) 68 for the figures relating to donkeys' walking speed when laden). Hypothetically Cicero's scenario is achievable within 24 hours; however Uggeri, La viabilità (n. 9, above) 297 estimated that Enna was two days from the sea at either Catana or Thermai Himerenses when taken at a normal pace.

${ }^{15}$ For details see Uggeri, La viabilità (n. 9, above) 14-19.

${ }^{16}$ It is possible that this latter route, noted in the Itinerarium Antonini but not the Tabula Peutingeriana, only became important in the Roman and late antique periods: for details see Uggeri, La viabilità (n. 9, above) 14-19 and 251-52.

17 The road from Messana to Catana is down a coastline that is so narrow that the modern road, the SS 114, in fact sits on top of the ancient road; Verbrugghe, Itinera (n. 9, above) 77. This particular feature makes it very difficult to trace the ancient road, although Verbrugghe noted that an ancient bridge is still standing over the Alcantara river, north of modern Taormina. In fact, the only location in which the SS 114 does not follow the ancient road in this area is under the promontory of Tauromenium, where the modern road tunnels through at the coast. 


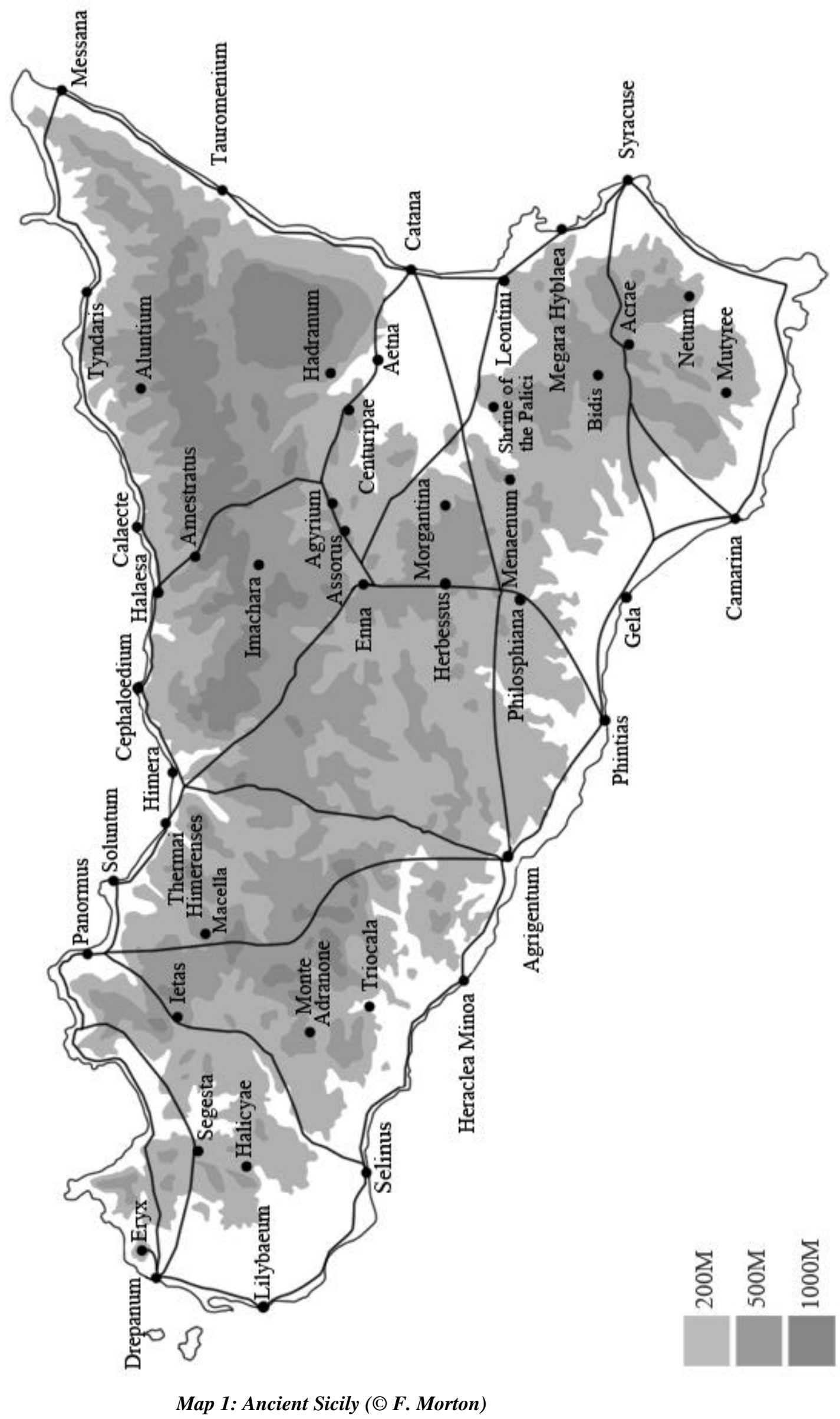


Moreover, in 260 or 259 when Carthage briefly experienced a resurgence in Sicily, we ought not to be surprised that one of the towns that was taken back, after the securing of Himera (Polyb. 1.24.3-4; Diod. Sic. 23.9.4), was Enna, which the Romans themselves swiftly retook (Polyb. 1.24.12; Diod. Sic. 23.9.4-5). Otherwise, the major fighting in Sicily took place around Lilybaeum, Drepanum and Panormus (Polyb. 1.38.5-10; 40.1-16; 41.4-45.14; 49.158.6). In sum, the fighting in the First Punic War was typically focussed on either important naval towns, or the cities of Sicily that controlled important intersections of the roads.

This remained the case even in the Second Punic War, despite the much more limited scope of the conflict. At one point, a Roman army under the command of Valerius Laevinus had landed at Panormus and was intended to march to Syracuse. The Carthaginian army, trying to intercept Laevinus, and knowing his destination, expected to catch him in central Sicily, presumably on the route from Himera to Enna (Liv. 24.36.4-6). They were then surprised when Laevinus instead marched to Messana, and then on to Syracuse; there were really only two routes that Laevinus could have taken, since at this point the Carthaginians held Agrigentum, thereby rendering the southern route impassable. This same layout of roads remained into the fourth century A.D. According to the tabula Peutingeriana the serviceable roads of Sicily operated on the coasts, with the sole exception of the route cutting from Catana to Enna, and on north to Himera. ${ }^{18}$ We would do well to consider what this meant for the actions of the rebels in Sicily in the second century BC.

\section{I.ii. 135-132 BC: Roads ${ }^{19}$}

In the course of the first war, between 135 and 132, the rebel forces seized five towns that we know of - Enna, Tauromenium, Morgantina, Agrigentum, and Catana (Diod. Sic. 34/5.2.2022; Strabo 6.2.6; Oros. 5.9.5) - with a strong likelihood that they attacked Syracuse as well. ${ }^{20}$

\footnotetext{
${ }^{18}$ G. Uggeri, 'La viabilità romana in Sicilia con particolare riguardo al III e al IV secolo', Kokalos 28-29 (198283) 424-60 (440).

${ }^{19}$ See the discussion below in section II concerning the date for the start of the first war.

${ }^{20}$ In a disconnected passage that is dateable to 133, Diodorus (34/5.9) records that a group of people suffered both in reality and in history because they ate sacred fish. This has been connected to the sacred fish of Arethusa at Syracuse (Bradley, Slavery and rebellion (n. 6, above) 60 and 110), and therefore to the rebels. Given that Diodorus had in book 5 of his Bibliotheke promised to record examples of those times when the taboo on eating the sacred fish at Syracuse had been broken, it seems likely that the passage refers to this particular pool: see J.
} 
There is no indication that they fought elsewhere on the island, and it can be suggested that the rebels limited their activity to the areas around and between these six towns (Map 2: Spread of first war). In the past, it has been argued that these choices of strongholds are examples of the rebels focusing on 'soft targets', ${ }^{21}$ thus emphasising their lack of a strategy beyond easy conquest, or targets chosen because of their suitability for passive resistance. ${ }^{22}$ Yet, we must take care not to simplify these achievements merely because they were eventually reversed: in the case of Enna, Tauromenium, Agrigentum and Syracuse it would only have required a small defence force to make them all difficult to capture, while, with the exception of Enna (Diod. Sic. 34/5.11-12), the sources offer no hint that these sites were unprotected. Moreover, these interpretations of why the rebels attacked these specific sites do not consider the topographical locations of these cities in relation to the road system.

Let us start with Enna. Even now, movement from the north to the south of the island is difficult, and the modern roads through the line of mountains across the north are precipitous. In ancient times, as we have seen, there were perhaps two roads to the north coast that did not hug the coast, ${ }^{23}$ or require a trip south to Agrigentum first, and they both passed either through or near to Enna. Control of this town was pivotal to control of movement across Sicily. Polybius (1.24.2) noted in his discussion of the First Punic War that the Roman capture of Enna secured central Sicily, and that in the Second Punic War Enna was secured, again by the Romans, in the most brutal fashion (Liv. 24.37-39). To the south, the town of Agrigentum had always been key to the fighting on the island. During the First and Second Punic Wars, Rome and Carthage fought repeatedly over the city, as it controlled a key route of access between the east and west of the island. While the terrain immediately surrounding Agrigentum consists largely of softly undulating hills, Agrigentum is

Malitz, Die Historien des Poseidonios, (München 1983) 158 no. 182 and 182; Bradley, Slavery and rebellion (n. 6, above) 60; C. I. R. Rubincam, 'Cross-references in the Bibliotheke Historike of Diodorus', Phoenix 43 (1989) 39-61 (41); Urbainczyk, Slave revolts (n. 8, above) 89-90; P. Wozniczka, 'Diodoros' narrative of the first Sicilian slave revolt (c. 140/135-32 B.C.) - a reflection of Poseidonios' ideas and style?', in Diodorus Siculus: shared myths, world community, and universal history, ed. L. I. Hau, A. Meeus, and B. Sheridan (Leuven 2014). However, it is unclear who it is eating the fish in the extract, making it very difficult to tell the circumstances that shaped the anecdote.

${ }^{21}$ Strauss, 'Slave wars' (n. 3, above) 195.

${ }^{22}$ Bradley, Slavery and rebellion (n. 6, above) 61-64.

${ }^{23}$ The route from Halaesa is of unknown quality, and is only included in the Ravenna itinerary, and not the tabula Peutingeriana or the Itinerarium Antonini, and so may not have been a major route. 


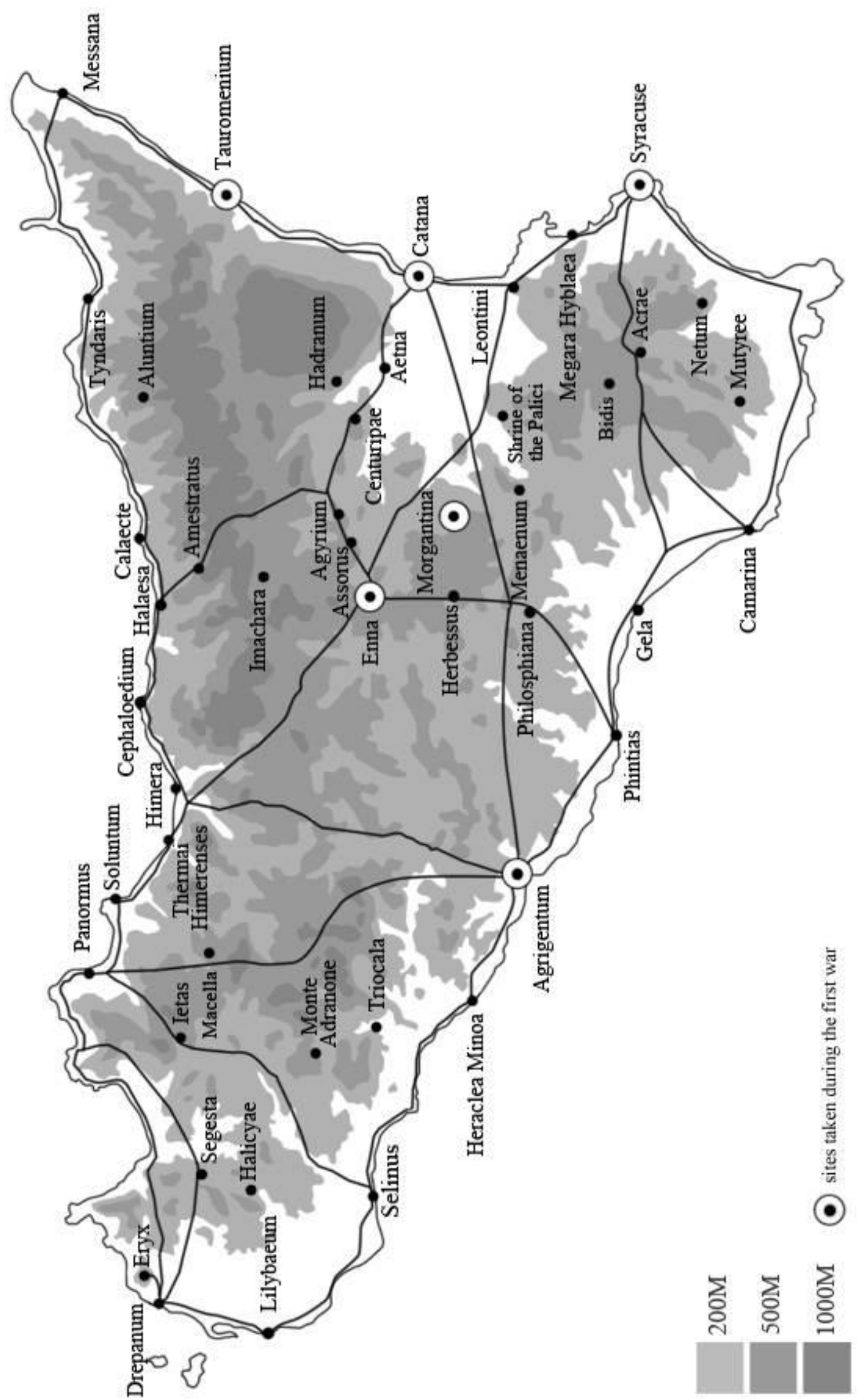

Map 2: Spread of first war (@ F. Morton) 
located at the convergence of the roads from Panormus and Himera, and moreover is ideally located to prevent easy access to any army hoping to move east from the west of the island. Control of this town, coupled with that of Enna, ensured that the rebels held control of all over-land communications through the centre of Sicily, and allowed them to prevent access to any forces from the west. These two towns also gave them, if needed, a second route to move north into the west of the island by taking one of two roads north from Agrigentum, to either Himera or Panormus.

With these two towns taken, the only unguarded route from the west was along the northern road to Messana and then down the coast, past Tauromenium to Catana. Catana, despite its location, was also an important city in terms of the Sicilian road system. The road north from Syracuse passed by Catana, and this town also was close to the route across to Enna and the northern of the two roads across the middle of Sicily west to Agrigentum; moreover, this road had several spurs that led to Bidis (modern day Vizzini) and modern day Licodia Eubea, immediately beside Bidis, from Leontini. Tauromenium sits astride the only access from Messana to the south by land. ${ }^{24}$ In this manner, the only access to the fertile grain fields of Leontini and Enna open to any hostile forces was from Syracuse: any other route would have required either a military engagement with the rebels in the citadels of Tauromenium, Enna, Agrigentum or (to a less formidable extent) Catana. Even access from Syracuse was problematic, since it entailed the strategic difficulty of pressing into the grain fields with an enemy harassing their flanks from Catana, ${ }^{25}$ and it appears that the rebels did indeed try to capture Syracuse as well.

In short, the only town taken by the rebels that was not strategically vital for the control of major thoroughfares is Morgantina, located, however, centrally in the grain fields. It appears, when viewed in the context of the Sicilian road network, that the rebels were

\footnotetext{
${ }^{24}$ Bradley, Slavery and rebellion (n. 6, above) 63-64) notes the strategic importance of these towns in relation to the roads of Sicily, but does not consider their broader strategic purpose in relation to logistics.

${ }^{25}$ Marching through hostile territory, even with a large infantry force, is demonstrably dangerous. V. D. Hanson, Warfare and agriculture in Classical Greece, (Pisa 1983) 21-25 stressed the severe limitations entailed in marching, while also devastating countryside held by hostile forces.. In particular, he noted that the light infantry used for foraging and devastation would require considerable protection from cavalry and infantry in formation while engaged in either activity, and this would reduce the mobility of any army forced into this expedient.
} 
trying to effect systematic control over the access routes of south-eastern Sicily. Understanding their efforts at exerting control over the geography of Sicily is vital to analysing their strategy in the war itself.

\section{I.iii. 135-132 BC: Strategy and Supply}

The analysis of the rebel strongholds enables us to consider an additional aspect of their strategy: supply. The importance of logistics cannot be stressed enough for warfare, ancient and modern. At the conclusion of his monograph on the logistics of the Roman army, Roth emphasised that the same attention must be given to the role of logistics in warfare by modern commentators as was given by the leading Roman generals of the ancient world. He noted that 'Protecting one's own supplies was a high priority and threatening or destroying those of the enemy a vital military mission, often preferable to deciding an issue through battle. ${ }^{26}$ The rebels' points of control in Sicily gave them control of access to eastern Sicily, with the sole exception of Syracuse, a failing they appear to have attempted to redress, as already stated above. While they could not cut off access to Sicily from Italy to Messana the rebels nonetheless held the main roads leading into the centre of eastern Sicily. ${ }^{27}$ They therefore controlled the two greatest grain growing regions of Sicily: Leontini and Enna. This does not imply that they completely cut off any Roman force on the island from provisioning itself from Sicily, but they made this far more difficult. While the west could produce grain, there were only a very limited number of routes from the west to the east.

This strategy alone, however, could not have defeated Rome, since the rebels did not appear to have access to a fleet, and therefore Rome could supply its armies by sea, moving supplies from magazines prepared elsewhere. Yet, by the simple act of denying the Romans supply directly from the fields of eastern Sicily, the rebels forced them into an extended logistical exercise, one which the rebels themselves sought to avoid. Given the limited nature of the evidence for the conflict, it is difficult to pinpoint this strategy beyond its topographical aspect, but some passages of Diodorus' narrative, as well as hints dropped by Florus, can provide some illumination. The first suggestion occurs in a fragment of Diodorus' narrative -

\footnotetext{
${ }^{26}$ J. P. Roth, The logistics of the Roman army at war: 264 B.C. - A.D. 235, (Leiden 1999) 333.

${ }^{27}$ In a later war on the same island, Sex. Pompeius corrected this strategic mistake. His resistance to Octavian's forces during the Roman civil wars of the 40s and 30s demonstrate the potential that Sicily held for long term resistance, provided that its coastal cities were held and adequately defended by naval forces.
} 
which may, given its position in the Constantinian excerpts, come from late in the war - that describes the collapse of order in Sicily (34/5.2.48):

When many great evils fell upon the $\Sigma ı \kappa \varepsilon \lambda \imath \omega \tau \alpha i$, the popular mob was not only unsympathetic to them, but on the contrary rejoiced, since they grudged their unequal fate and irregular way of life. For envy arising from earlier suffering turned into joy, when the mob saw that the success deriving from chance had changed into a form previously overlooked by it. Most terrible of all, the rebels, exercising rational forethought concerning the future, neither set fire to farm houses nor damaged the stock in them and the harvest lying in store, and held off from those who had turned to farming. The populace, however, because of their envy, and behind the pretext of the runaways, went out into the countryside and not only plundered the estates, but even set fire to the farm houses. ${ }^{28}$

In accordance with the strategy implied by the rebels' choice of strongholds, they held off from ravaging the countryside with the future in mind: provision was a foremost concern. ${ }^{29} \mathrm{It}$ is especially noteworthy that they left alone the buildings, and harvests lying in store, quite unlike what a hostile army would have done. ${ }^{30}$ Even more than this, the rebels left alone those farming, seeking, it seems, to preserve the productive capacity of the area. In short, in the context outlined here, the rebel forces appear to be treating the territory of Sicily they

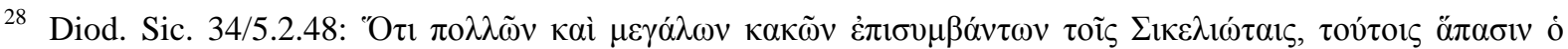

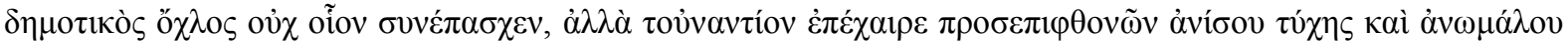

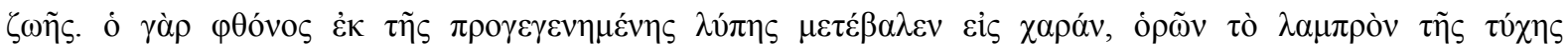

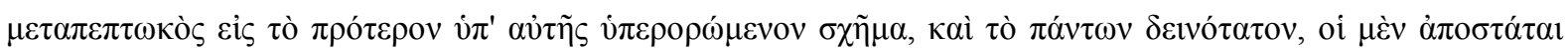

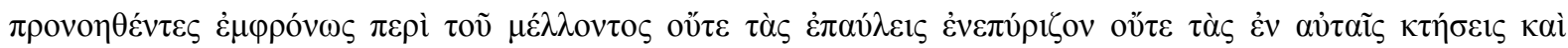

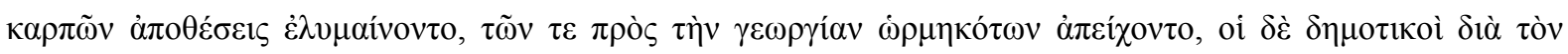

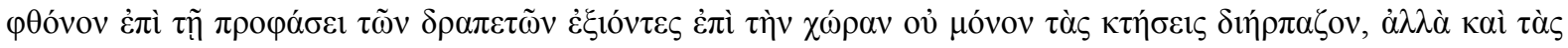

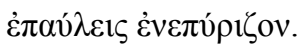

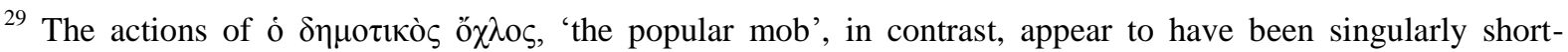
sighted. Nonetheless, the stress laid by Diodorus on the looting of estates perhaps points towards the origin of

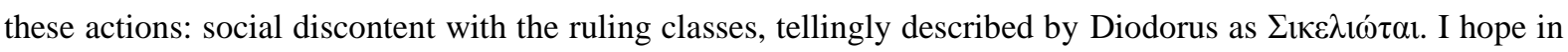
the future to discuss this passage and its implications for Sicilian society.

${ }^{30}$ Hanson, Warfare and agriculture (n. 25, above) 42-46 and 58-63 notes that it was the aim of ancient armies in hostile terrain to destroy the buildings, and torch the grain lying in store. 
controlled as their home ground, and were engaged in a protective strategy toward the farmers on the island.

Moreover, another incident from the war stresses the sustained importance of supply to the two opposing forces. Later in the campaign, in 132, the consul Rupilius retook the citadel of Tauromenium through starvation, and despite the compressed nature of the passage, the importance of provisions is clear (34/5.2.20):

In Sicily the trouble was increasing, and cities were being captured together with their men, and many armies were cut to pieces by the rebels, until Rupilius, the Roman general, recovered Tauromenium for the Romans, after a severe siege and enclosing the rebels in unutterable duress and hunger, so that beginning with the flesh of the children and progressing through the women, they did not altogether abstain from eating the flesh of each other... ${ }^{31}$

While the site of Tauromenium was, in terms of the communications of Sicily, vitally important, it was, through its geographical location, hard to supply. It is clear that Rome had successfully neutralised the rebel strategy at this point, and put their forces, at least in Tauromenium, in a position of extreme hardship. Yet, perhaps the most telling evidence of the rebel strategy is the notice preserved in Florus of the capture of praetors' camps during the conflict (2.7.7). There is no indication in the passage of the nature of these camps, but it is possible that they were more than just marching camps. If the praetors named by Florus were serving alongside consular commanders, as suggested by Brennan, ${ }^{32}$ then it is quite plausible that the praetorian commanders were assigned to the operational and tactical bases, therefore making these camps a vital link in the Roman supply lines. Even if this was not the case, however, Roman marching camps also functioned as supply bases, and therefore their capture

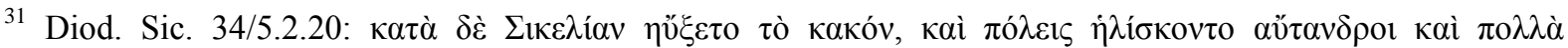

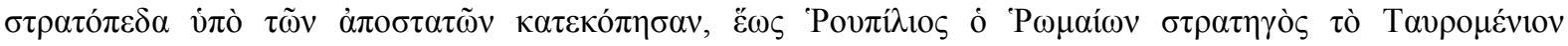

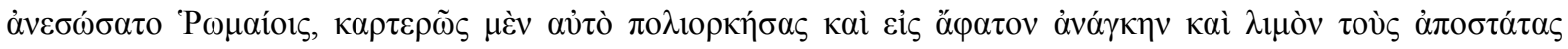

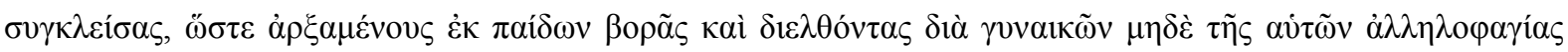
$\mu \eta \delta^{\prime}$ ö $\lambda \omega \varsigma$ $\varphi \varepsilon i ́ \sigma \alpha \sigma \theta \alpha 1 \ldots$

${ }^{32}$ T. C. Brennan, 'The commanders in the First Sicilian Slave War', RFIC 121 (1993) 153-84.
} 
represents a significant tactical victory for the rebel forces, as well as a military embarrassment for Rome. In sum, the rebel forces were capable of openly engaging with Rome's forces, and it is very likely that this capability was achieved, at least in part, through their strategic control of Sicily, and their strategy of targeting the supply lines of Rome.

\section{I.iv. 104-101 BC: Roads}

While the evidence for the chronology and geography of the conflict that raged less than 30 years later is in some ways much more complete than for the events in the $130 \mathrm{~s}$, it nonetheless contains frustrating lacunae. In what follows, I will reconstruct as far as possible the geographical extent of the conflict. This in turn will be related to the roads of Sicily. The first action of the war was the revolt led by Salvius/Tryphon near Heraclea Minoa (Diod. Sic. 36.4.1-2). The actual location of the rebels at this point is unclear from the narrative. In Diodorus' reconstruction, the governor marches past the rebels in order to reach Heraclea, and crossed the river Alba (36.4.2). Diodorus also notes that the rebels succeeded in their first engagement because they held difficult terrain (36.4.3); in this case it is perhaps best to place them in the elevated region to the north of Heraclea. From here the rebels, under the command of Salvius/Tryphon, then proceeded to besiege Morgantina (36.4.5), and on their failure to complete the siege they then withdrew first to the shrine of the Palici (36.7.1), and then to a place called Triocala (Map 3) ${ }^{33}$ back in the west of the island (36.7.2). After this, we hear only of the rebels' defeat at Scirthaea ${ }^{34}$ and then their subsequent defeat by the Romans in the following years (36.8-10).

Diodorus informs us of a second group of rebels in this period, commanded by Athenion. This group presents their own problems for the current discussion. We first hear of Athenion in the area around Segesta and Lilybaeum (36.5.1). After his initial success he then briefly besieged Lilybaeum (36.5.3), and according to Diodorus was then summoned to Salvius/Tryphon's force, and met him at Triocala (36.7.2). Furthermore, in a fragment of Dio,

\footnotetext{
${ }^{33}$ Triocala is most likely modern day Sant'Anna below Caltabellotta; see G. Bejor, 'Ricerche di topografia e di archeologia nella Sicilia sud-occidentale', ASNP 5 (1975) 1275-1303 (1283-89) and E. Manni, Geografia fisica e politica della Sicilia antica, (Roma 1981) 238-39.

${ }^{34}$ The exact location of Scirthaea is unknown. See Manni, Geografia fisica (n. 33, above) 222, for an identification of Scirthaea with San Carlo, north of Caltabellotta, on the modern road SS 386; and Bejor, 'Ricerche di topografia' (n. 33, above) 1282-83, for other possible identifications.
} 


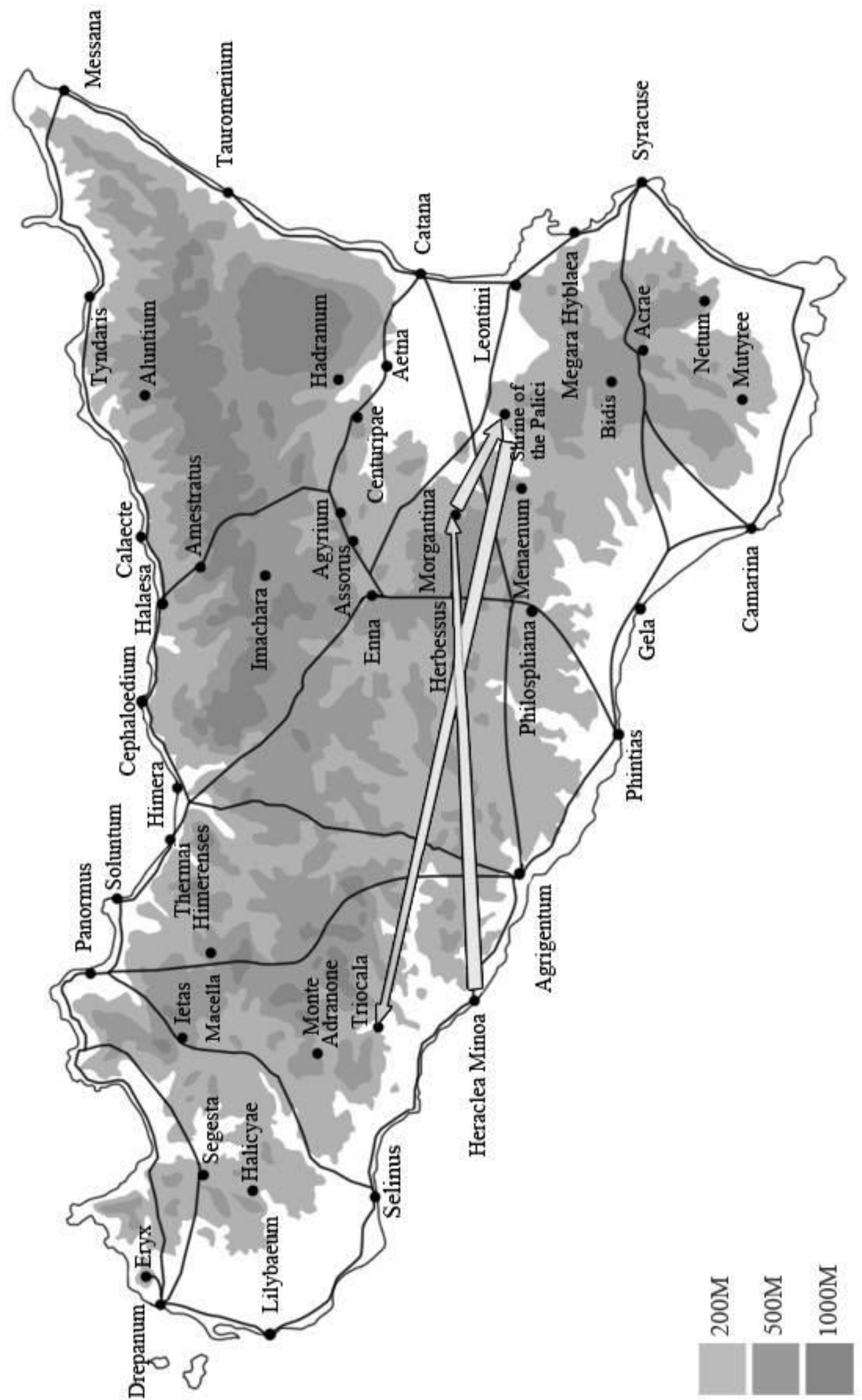




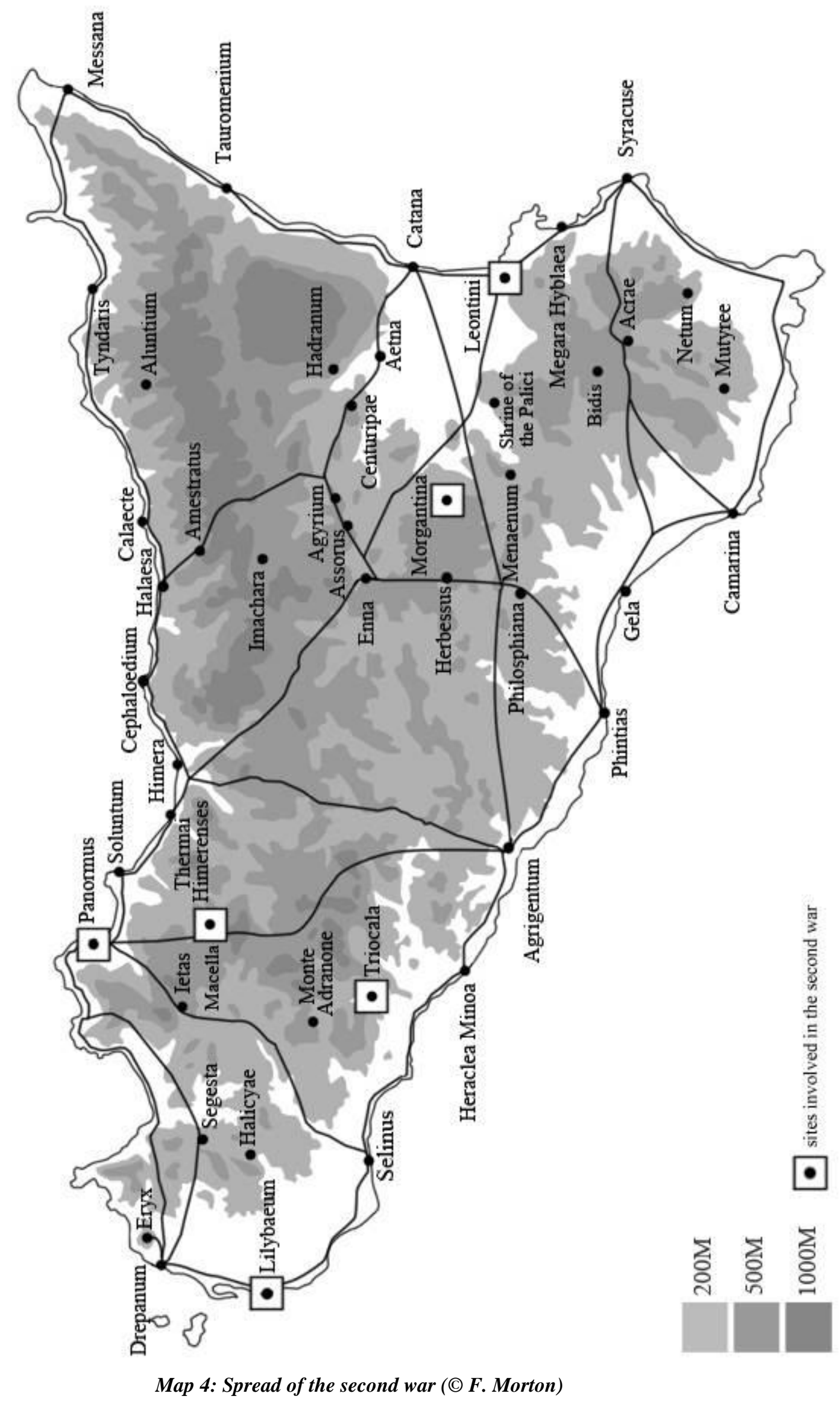


we hear that Athenion had fortified the site of Macella with a wall (27.93.4). ${ }^{35}$ We cannot provide a strict chronology for these movements, and our other sources for the rebels' movements in this period, slingshots, do not help much either. There is a small number of slingshots bearing Athenion's name which have been found in a number of places across Sicily (IG 14.2407,8a-d). ${ }^{36}$ Of these, two have no find spots recorded (c and d). The other two are recorded as being found near Leontini (b) and in the area of Palermo (a). Their find spots

35 The fragment is problematic. It starts by describing an attack by Athenion on the people of Messana,

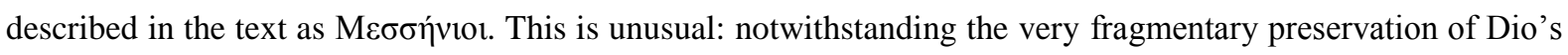
text, the inhabitants of the town of Messana, following its capture by the Mamertines, are consistently called

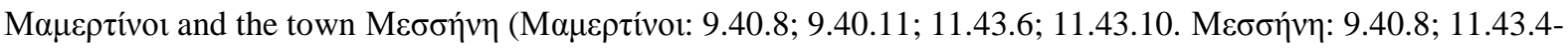
9 (three times); 48.17.4-5 (twice); 49.2.1; 49.5.1-2 (twice); 49.7.4; 49.10.2 (twice); 49.11.2-4 (twice); 49.17.1). This usage is continued by Zonaras where he follows Dio. I would tentatively suggest that the usage of

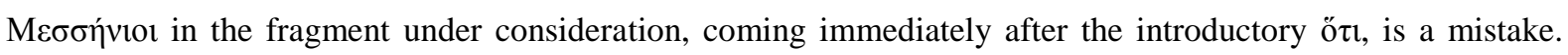
Support for this suggestion comes from the remains of the fragment. Immediately following the attack on Messana the fragment moves quickly to the fortification of Macella with a wall. Macella is now thought to have been on the site of modern Montagnola di Marineo, as attested by three inscribed roof tiles (SEG 511377 and 54 927). For the publication of the roof tiles, see F. Spatafora, 'Un contributo per l'identificazione di una delle “città di Sicilia" dei decreti di Entella', in Da un'antica città di Sicilia. I decreti di Entella e Nakone, ed. C. Ampolo (Pisa 2001) 111-14, and in F. Spatafora and S. Vassallo (ed.), Das Eigene und das Andere. Griechen, Sikaner und Elymer. Neue archäologische Forschungen im antiken Sizilien (Palermo 2004) 108 nos. 208/209. Since Macella is so far from Messana, and yet the two episodes are connected in the fragment, this lends weight

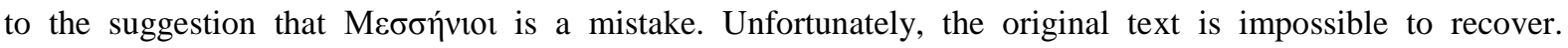
Therefore, without further information pointing to an attack on Messana, I do not include it in my reconstruction of the rebel movements.

${ }^{36}$ G. Manganaro (see his 'Monete e ghiande inscritte degli schiavi ribelli in Sicilia', Chiron 12 (1982) 237-44 (241) and 'Onomastica greca su anelli, pesi da telaio e glandes in Sicilia', ZPE 133 (2000) 123-34 (131-32)) has published a number of other slingshots which seem to relate to Salvius/Tryphon. If we accept his reconstruction of two slingshots in particular (which Manganaro noted at 'Onomastica greca' (n. 36, above) 130 figs 34a-b), which do not appear in $I G$, then there would also seem to be slingshots bearing Salvius' royal name, Tryphon, found near to the suggested site of Triocala. Sadly, these slingshots tell us nothing more about the war, merely bearing the inscription NIKA/TPY $\Omega$ NOC. Furthermore, in $I G X I V$ there are a total of 26 entries recording slingshot finds in Sicily, and these have been variously attributed to the forces either for or against the insurgency based upon their choices of deities or specification of which city and unit thereof the slinger came from: see, e.g. Manganaro, 'Monete e ghiande' (n. 36, above) 243; Bradley, Slavery and rebellion (n. 6, above) 75 n. 14 and 80 n. 22; Manganaro, 'Onomastica greca' (n. 36, above) 130-33; Shaw, Spartacus (n. 7, above) 128-29. Without better archaeological contexts, however, we cannot state their date or target. Until this evidence is brought to light, we must restrict ourselves to using only the slingshots that explicitly state their commander. 
would appear to indicate actions by men under the command of Athenion in the plains of Leontini and at Panormus.

The find spot near Leontini is best placed during the praetorship of Servilius, when Diodorus recorded that Servilius' inaction allowed Athenion to plunder freely across the island (36.9.2). The slingshot found near Palermo, on the other hand, could have been fired during the rebel actions around Macella, and allows us to suggest an extension to the area affected by the rebel actions in this period, notwithstanding the possibility that the slingshots 'travelled'. From all of the evidence for the second war, we can demonstrate that the rebels fought in an area spreading from Lilybaeum to Leontini - an area that encompasses a large part of Sicily (Map 4). It appears that in some respects the rebels in this war were attempting to mimic the strategy of the first: they controlled a small area around Triocala supplemented with the site of Macella - and attempted to spread this control into the grain fields of the east by attacking Morgantina and Leontini. The noteworthy difference is that the rebels in the second war were far less successful in their endeavours. Most importantly, they were unable to seize any of the locations they attacked, with the exception of the isolated citadel of Triocala and the town of Macella, neither of which was fortified until after being taken by the rebels. This, in turn, affected their strategy with regard to supply.

\section{I.v. 104-101 BC: Strategy and Supply}

As we have seen, the rebels in the second of the two conflicts under discussion here attacked widely across the island, but never succeeded in maintaining control over Sicily in a systematic manner. This, in turn, meant that the rebels did not control the most productive grain regions of Sicily, which were located to the southeast and far west of the island. In fact, they actually withdrew from these regions to the mountainous parts of the southwest for their fixed base after their failure at Morgantina (Diod. Sic. 36.7). Evidence from Diodorus indicates that, throughout the conflict, the rebels held a strong position in the open countryside. This was the case both following the withdrawal of L. Licinius Nerva from the island after his defeat at Morgantina, and after their defeat by Lucullus following his failure to follow up the victory, and the disbanding of his army $(36.6,7.1,9.2,11)$. Despite their fortresses at Triocala and Macella, the rebels appeared to resort to random plundering for their supply in the absence of any apparent Roman threat to their movements (36.11.1). It is not possible to discern any coherent strategy with regard either to the supply of their army or 
to the hindering of their enemies' supply in the actions of Salvius/Tryphon and Athenion with two exceptions.

First, while chronicling Athenion's rise in the west of the island, Diodorus records a detail of Athenion's initial strategy. Early in the campaign, Athenion acted differently from the other rebels (Diod. Sic. 36.5.2-3):

When he had been chosen king by these men and had put on a diadem, he adopted the opposite disposition to all the other rebels. For he did not accept all who revolted, but making soldiers of the best he compelled the others to remain at their previous work, and each to engage in their own domestic affairs and post; therefore he was able to furnish plentiful provisions for his soldiers. He pretended that the gods foretold to him through the stars that he would be king of all Sicily: therefore there was a need to spare the land itself, the animals on it and the crops as his own.

At first glance, the order for some to remain at their normal domestic posts is indeed a sensible strategy. This passage is typically taken as demonstrating the manner in which Athenion provided his troops with a secure food supply. ${ }^{37}$ Bradley stressed, moreover, that this reflected 'a rational, even sensible and enlightened, character in the slaves' actions'. ${ }^{38}$ However, this uprising, and the order for some to remain at work, was based in the extreme west of the island (apparently in the territory between Segesta and Lilybaeum). Without a demonstrable long-term strategy from Athenion to secure the safe labour and exploitation of those that were left on the land, far from the rest of the revolt, this view of his actions is problematic. For regardless of how well this might have secured a short-term supply of food, the subsequent actions of Athenion reveal a lack of strategic foresight about the maintenance of this organisation (Diod. Sic. 36.5.3-4):

\footnotetext{
${ }^{37}$ So A. I. Toynbee, Hannibal's Legacy, 2 Volumes (London 1965) II, 329; Vogt, Sklaverei und Humanität (n. 5, above) 34-35; Bradley, Slavery and rebellion (n. 6, above) 76-77; Wirth, Katastrophe (n. 8, above) 284; Urbainczyk, Slave revolts (n. 8, above) 57.

${ }^{38}$ Bradley, Slavery and rebellion (n. 6, above) 110.
} 
Finally, having gathered more than ten thousand, [Athenion] undertook to besiege the city of Lilybaeum, which had never been captured. After accomplishing nothing he removed himself from it, saying that the gods ordered this: for were they to continue the siege they would experience misfortune. While he was preparing to retreat from the city, some ships put in carrying Mauretanian auxiliaries, who had been sent to help Lilybaeum, having as leader one called Gomon. He, with his men, unexpectedly attacked those walking with Athenion in the night, killing many, wounding not a few, and returned to the city. As a result, the rebels wondered at the prediction from the stars.

The withdrawal from Lilybaeum was disastrous for Athenion's forces, and this is hardly surprising if Mauretanian auxiliaries harassed his marching column. Furthermore, his withdrawal, followed soon afterwards by the summons to Triocala from Salvius/Tryphon (36.7.2) meant that any arrangements made near Lilybaeum and Segesta had to be abandoned, with heavy casualties in this case. While we never hear of these Mauretanian auxiliaries again, it is reasonable to presume that they secured the territory around Lilybaeum after Athenion's withdrawal. Given our comparative lack of any information regarding the rebels' strategy after this point beyond what can be taken from their geographical locations (which stress action in a corridor between Triocala, Morgantina and Leontini), and a single passage of Diodorus that comments on the ad-hoc, plundering nature of rebel supply (36.11.1), ${ }^{39}$ we cannot use this evidence to argue for an enlightened approach. It seems to be, rather, a brief experiment, quickly abandoned by Athenion when he was forced out by superior forces. These superior forces then, we can surmise, made certain that the territory in which Athenion had made his arrangements were no longer under his control.

Beyond this, we hear, in a very confused narrative from Florus, that the rebels routed the armies and captured the camps of Servilius and Lucullus (2.7.11). This would appear to give a similar impression of a successful rebel strategy as in the other war; however, the rebel successes in the later conflict were aided as much by Roman incompetence as by rebel skill. L. Licinius Lucullus defeated the rebels in pitched battle (Diod. Sic. 36.8.3-5), but failed to

\footnotetext{
${ }^{39}$ It seems, from a brief comment in Cicero's De Lege Agraria, that the devastation described by Diodorus may well have been quite effective: Cicero noted that in 101, when consul, M'. Aquilius had to lend grain to the cities of Sicily (2.83), a most unusual situation.
} 
follow this success up, and actually destroyed his own camp and disbanded his soldiers in order to hamstring his successor Servilius' chances in the campaign (Diod. Sic. 36.9.2). This is not to detract from the achievement of capturing praetors' camps, but it must be remembered that Servilius in particular was the recipient of a command denuded of any military assets by his predecessor, Lucullus. Taken altogether, there is a comparative lack of evidence for a clearly defined strategy among the rebel forces 104-101.

\section{Comparisons}

When we consider both wars in terms of how they were fought by the rebels, and especially at the strategic level, the perspective's potential becomes immediately clear. In the first war, the rebels fought across a tight geographical context. This tight geographical spread is best understood as an effort to implement a strategic plan for the prosecution of the war in a manner that is reminiscent of other mismatched forces that had to contend with the might of Rome. Therefore, the rebel strategy entailed a concerted undertaking to control the lines of supply in Sicily, reflected in the choices of strongholds, rather than a desire to withdraw from Sicily into defensible sites in a form of marronage, or simply plunder the province to survive short term, as has been argued in the past. The later war, by contrast, betrays a much less clear strategy in regard to control of territory and food. If we compare the spread of conflict in 104-101 to the spread during 135-132, an immediate and important difference is apparent (Map 5). Whereas in the first war the locations attacked and taken were sites that had systematic strategic importance to the island's communications and supply, especially east to west, the rebels of the second war appear to have attacked areas across the bulk of the island, from Lilybaeum, Triocala, and Macella in the west, to Morgantina and Leontini in the east. Moreover, the first war had a tight geographical focus, clearly situated in the east of Sicily, in definite contrast to the wide ranging fighting in the second war. Perhaps most importantly of all, the rebels in the second war were not successful in any of their attacks. Unlike those in the first war, whose conquests were not only strategic, but also largely successful, ${ }^{40}$ Salvius/Tryphon and Athenion actually withdraw from all the major roads between Agrigentum, Panormus and Himera once in Triocala, which if identified with Sant'Anna (see n. 33) is on a rising slope above the countryside around it,

\footnotetext{
${ }^{40}$ Indeed, the major failing of the strategy outlined here was that the rebels failed to take Syracuse, the capture of which would have cut off Rome from any major harbour on the east coast south of Messana.
} 


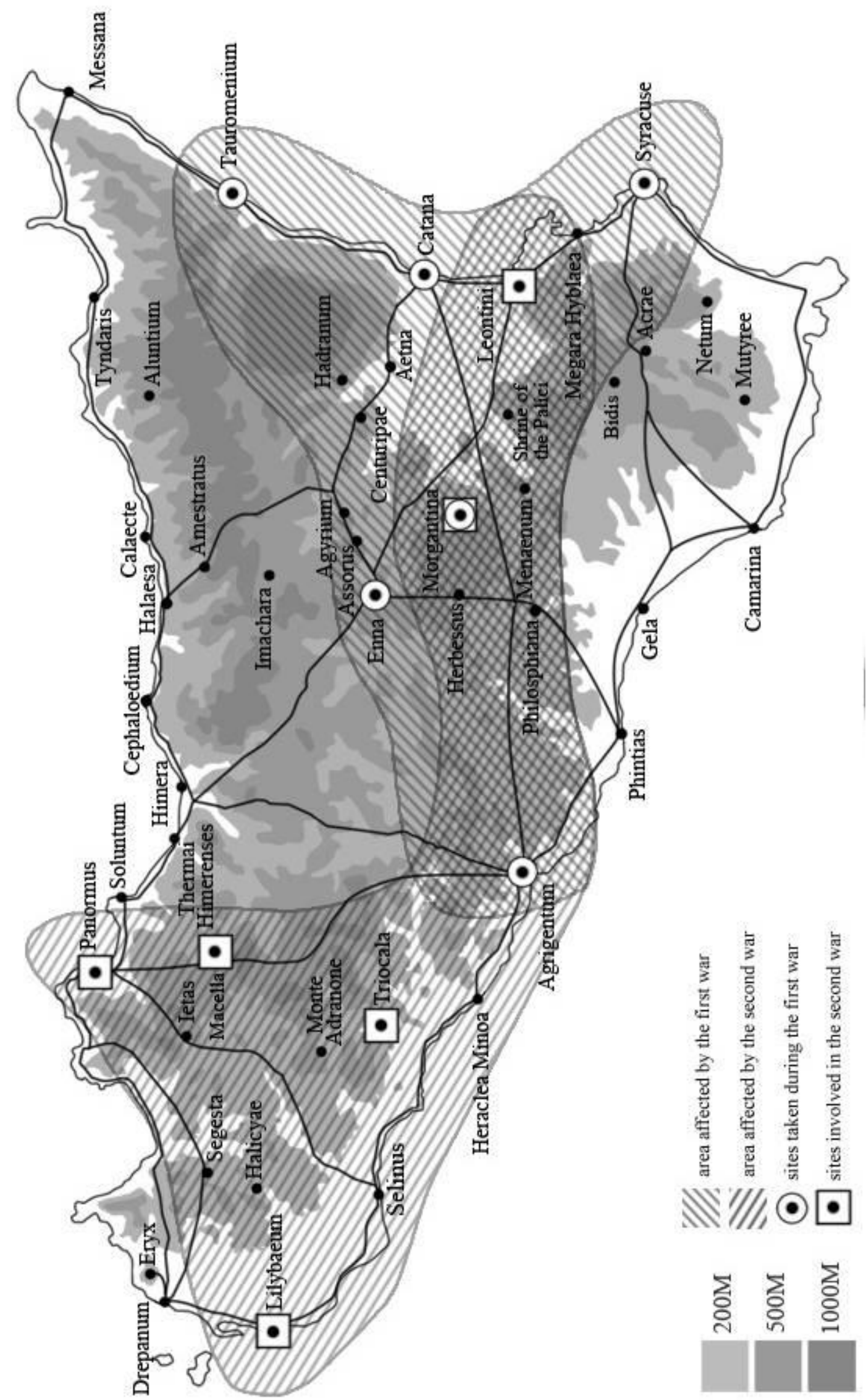

Map 5: Comparison of the spread of the two wars (@ F. Morton) 
with no access north from the site. Their forces utilised the roads, certainly, but never controlled them systematically as the earlier rebels had managed to. The few locations they succeeded in securing did not allow effective intervention against hostile forces moving along the major routes, except perhaps through the fortification of Macella: Salvius/Tryphon and Athenion could dominate the countryside - largely thanks to Roman incompetence - but could not control the cities.

\section{II.i Comparisons: Rome's Responses}

We cannot, when viewing the two conflicts from the perspective here adopted, realistically regard the two wars as the same types of conflicts without ignoring the clear disparity between them in terms of the rebel strategies. Once we do recognise the differences we can also better contextualise the Roman approaches to these events. Thus, whilst the best estimates suggest that both wars were essentially of the same length, there are a number of clear distinctions. While the second war was fought on the Roman side by a single praetor, until the final year of the conflict when a consul was sent to conclude the war, the first war escalated quickly in terms of Rome's response. If we follow the reconstruction of Roman commanders in the war proposed by Brennan and Keaveney, then we can see that the war was fought, after the first year, by, at the very least, one consul each year, most likely with a praetor or propraetor serving alongside (Table 1). ${ }^{41}$ When compared in this way, we can see that Rome viewed the two conflicts as deserving very different responses, as we might expect given the very different strategies (and successes) of the rebel forces in the two wars.

Table 1: Roman generals in Sicily, 135-132 and 104-101

\begin{tabular}{|l|l|}
\hline 'First Sicilian Slave War'42 & 'Second Sicilian Slave War' \\
\hline
\end{tabular}

\footnotetext{
${ }^{41}$ Brennan, 'The commanders' (n. 32, above) and A. Keaveney, 'Three Roman chronological problems (141132 B.C.)', Klio 80 (1998) 66-90. Even if we reconstruct the list of Roman commanders in a more traditional manner, and date the start of the first war to 138 , it still remains the case that the first war was fought by successive generals for seven years, the last three of which were fought by consuls.

${ }^{42}$ The reconstruction of commands in this war is very difficult, but it is reasonably safe to say that the war, from the Roman perspective at least, started in 135; Florus' list of defeated praetorian commanders (2.7.7) is the cause of considerable problems, and so the table gives in brackets those commands that have been tentatively suggested by Brennan, 'The commanders' (n. 32, above) and Keaveney, 'Three problems' (n. 41, above).
} 


\begin{tabular}{|l|l|}
\hline 135 - praetor, (praetor) $^{43}$ & $104-$ praetor $^{44}$ \\
\hline $134-$ praetor, consul, (praetor) $^{45}$ & $103-$ propraetor $^{46}$ \\
\hline $133-$ praetor, consul, (propraetor) $^{47}$ & $102-$ praetor $^{48}$ \\
\hline $132-$ consul, (propraetor) $^{49}$ & $101-$ consul $^{50}$ \\
\hline
\end{tabular}

Moreover, this table does not tell the whole story. While on this reconstruction both wars were of the same length, the longevity of the latter event owed much more to Roman incompetence than rebel strategy or tactical skill, as we saw above. On each occasion that the rebels fought the Roman forces in the field, they were defeated: in 103, Lucullus defeated the rebels at Scirthaea despite being outnumbered (Diod. Sic. 36.8.3-5); in 101, Aquilius broke the back of the resistance in a single engagement (Diod. Sic. 36.10.1). Moreover, the inaction of the praetor of 102 was caused by his predecessor disbanding the army in the province, and destroying the camps (Diod. Sic. 36.9.2). This is quite in contrast to the events in the first conflict, in which the rebels captured several important locations, some of which were taken even while a Roman consul was operating in the area. It is important to note how differently

\footnotetext{
${ }^{43}$ It is reasonably certain that Lentulus served in Sicily in either 136 or 135 either as praetor, or as propraetor after a praetorship elsewhere in 136. If we follow the order of commanders given by Florus, perhaps also Manlius served as praetor this year as well (Flor. 2.7.7; so Keaveney, 'Three problems' (n. 41, above) 77, 79), although see Brennan, 'The commanders' (n. 32, above) 176, for arguments that L. Plautius Hypsaeus served as praetor in 135.

${ }^{44}$ P. Licinius Nerva served as praetor (Diod. Sic. 36.4.6).

${ }^{45}$ See Keaveney, 'Three problems' (n. 41, above) 76-80, for arguments placing L. Plautius Hypsaeus as praetor in 134 (Diod. Sic. 34/5.2.18). Certainly C. Fulvius Flaccus was consul (Liv. Per. 56; Julius Obsequens 27; Oros. 5.9.6) perhaps alongside T. Manlius as praetor (Flor. 2.7.7; see for this Brennan, 'The commanders' (n. 32, above) 177).

${ }^{46}$ L. Licinius Lucullus, having served as praetor in Italy in 104, was appointed to the command, presumably as propraetor, in 103 (Diod. Sic. 36.8.1).

${ }^{47}$ L. Calpurnius Piso as consul (Val. Max. 2.7.9, 4.3.10; Oros. 5.9.6) alongside M. Perperna and T. Manlius as praetor and propraetor respectively (Flor. 2.7.7; see Brennan, 'The commanders' (n. 32, above) 177, for the suggestion that T. Manlius served as propraetor in this year).

${ }^{48}$ C. Servilius served as praetor (36.9).

${ }^{49}$ P. Rupilius as consul (Diod. Sic. 34/5.2.20; Cic. Verr. 2.4.112; Val. Max. 2.7.3, 6.9.8, 9.12.1; Liv. Per. 59), perhaps with M. Perperna as propraetor (see Brennan, 'The commanders' (n. 32, above) 177, for this suggestion).

${ }^{50}$ M'. Aquilius served as consul in 101 (Diod. Sic. 36.10.1), and subsequently held a proconsulship in 100 (Diod. Sic. 36.10; Flor. 2.7.11-2; Obseq. 45; Cic. Verr. 2.3.125, 5.5 and 14), and perhaps continued his proconsulship into 99 (see Liv. Per. 69).
} 
Rome considered the two conflicts: in the first, Rome quickly escalated its forces in the region, deploying successive consuls to eliminate a force in possession of several important citadels of eastern-Sicily; in the second, Rome appointed a succession of praetors, only finally sending a consul to conclude the war after two years of incompetence and political infighting had hampered what should have been a simple matter for the forces on the island. The Roman response in each case highlights what the strategic comparison given above has already shown: these two conflicts were very different.

\section{Conclusions}

In c. 93, the Roman governor of Sicily, a certain L. Sempronius Asellio, recovered

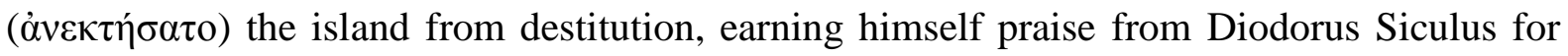
his efforts (37.8). ${ }^{51}$ The peculiarity that it was Asellio - and not Aquilius, the victor of the second war discussed here - who was credited by Diodorus with this recovery reflects in part Rome's changing attitude towards provincial matters at the turn of the first century BC. ${ }^{52}$ The lex de provinciis praetoriis and Q. Mucius Scaevola's governorship of Asia Minor are further evidence of Rome's concern to correct in some way provincial misadministration and it appears, from Diodorus' perspective at least, that Asellio's actions were the Sicilian component of this process. ${ }^{53}$ His governorship apparently ended a period, starting in the $130 \mathrm{~s}$, in which the problems of Sicily occupied not only the historians interested in the era, but the

\footnotetext{
${ }^{51}$ See T. C. Brennan, The Praetorship in the Roman Republic, (Oxford 2000) 480 and 747 n. 263, for arguments in support of dating Asellio to 93.

${ }^{52}$ In $71 \mathrm{BC}$, a moneyer from the Aquilii produced a denarius (RRC 401/1) celebrating Aquilius' actions in restoring the province, showing on its reverse a Roman soldier helping a personification of Sicily to her feet; this presents a very Roman view of Aquilius' actions, not least because from a different perspective, it was Asellio, and not Aquilius, who recovered the island in the broader sense. On the coin itself, see J. R. W. Prag, in Sicilia Nutrix Plebis Romanae: Rhetoric, Law and Taxation in Cicero's Verrines, ed. J. R. W. Prag (London 2007) vi.

${ }^{53}$ For historical commentary on the lex de provinciis praetoriis, see in the first instance M. Hassall, M. Crawford and J. Reynolds, 'Rome and the eastern provinces at the end of the second century B.C.', JRS 64 (1974) 195-220 (esp. 218-20). Scaevola's, through his governorship of Asia Minor, became renowned as the model governor: see $M R R$ II 7-9 for primary references to his governorship, and the subsequent condemnation of his legate, P. Rutilius Rufus.
} 
attention and armies of the Romans. Whatever the precise causes of the two conflicts, ${ }^{54}$ they manifested themselves strategically in very different ways. It is clear in this context that we have to understand the two wars as entirely different events concerning their military and logistical natures.

This conclusion raises a much more pressing question: if these two wars were fought with such different levels of military organisation, strategy, and success, can we rule out that there were deeper differences between the two? Should we understand other aspects of the conflicts as fundamentally different as well? An analysis of that kind is not possible here. Nonetheless, it is important to note that by continuing to discuss these conflicts under the misleading umbrella term of 'slave wars', we perpetuate the skewed view that the two episodes (which Diodorus Siculus has forged into a natural sequence of servile dissatisfaction) represent strategically and historically similar situations. The present analysis has, in contrast, given each conflict its due share of attention - albeit here focused only on the strategic elements of the wars. Further analysis of this kind is likely to expose additional differences between what have up to this date been understood by modern scholarship, in an unduly harmonising fashion, as consecutive episodes of the Sicilian experience with slaves: the differentiated Roman approach to the conflicts may be a better guide to the historical truth. ${ }^{55}$

\footnotetext{
${ }^{54}$ There are hints in Diodorus $(34 / 5.2 .48 ; 36.6,11)$ that matters on Sicily were more complex than is generally allowed in modern analyses of these events. These passages concerning the two wars indicate that free Sicilians played a major part on both sides of the conflicts, and that the causes of the unrest in Sicily were wider reaching than the complaints of the servile portion of the population; however, a full analysis is outside the remit of this paper.

${ }^{55}$ This point has been made from a different perspective on the basis of a detailed analysis of Diodorus' depiction of the rebel leader in the first of the two wars in P. Morton, 'Eunus: the cowardly king' $C Q 63.1$ (2013) 237-52.
} 